supportive community that participation in the Council for a Democratic Germany and The German American had helped to create? What about their political, social, professional, and artistic status in those years? In the following chapters, the author illustrates these issues through individual cases. One of the most striking facts is that these communist remigrants became the subject of the surveillance and repressive measures of the GDR's state security apparatus, just as they had been subject to surveillance by the FBI in the USA (see Chapters Four and Six). The methods of those institutions were almost identical, but the motives for the suspicions and persecution were quite different.

In this meticulous, biographically based study, Mario Kessler offers a whole panorama of the history of the German communist "West émigrés" with regard to ideas and ideology, politics and policies, social life and mentality. In doing so, Kessler also offers us an insight into the psychological disposition of those who led the GDR.

Ursula Langkau-Alex

International Institute of Social History PO Box 2169, I000 CD Amsterdam, The Netherlands E-mail: ula@iisg.nl doi:10.1017/S002085902000067X

Tronti, Mario. Workers and Capital. Transl. [from Italian] by David Broder. Verso Books, London [etc.] 2019 (197I). xxxv, 364 pp. £70.00. (Paper: £19.99; E-book: $\left.\mathfrak{£}_{1} 6.99\right)$.

There are few single books in the postwar Marxist tradition that can claim to not only have instigated a new "school" of Marxist thought, but also a current of political militancy still prominent among sections of the "radical Left" today. While one might fairly speak of Louis Althusser et al.'s Reading Capital as an example of the former, any concerted attempt to extract a form of political practice - let alone militancy - from such a tradition, I would contend, is a forlorn one. One might turn to Liberation Theology, Black Marxism, or Marxist Feminism as currents of thought and militancy that have combined theoretical innovation within a broad Marxist tradition and practice, but it would be difficult to find a single foundational text recognized as such by those seeking to establish their own politico-theoretical lineage. Perhaps the only text that could make the claim of having done both is Mario Tronti's Workers and Capital, a book collecting writings composed over a decade between 1962 and I97 I. Typically, the core idea of operaismo (often mistakenly confused with "autonomism") is summarized in three sentences from Tronti's "Lenin in England": "We too saw capitalist development first and the workers second. This is a mistake. Now we have to turn the problem on its head, change orientation, and start again from first principles, which means focusing on the struggle of the working class.” To put this differently, rather than focus on where capital is weakest, one must turn to where the working class is strongest. Rather, therefore, than a focus on the worker, on the categories of labour or labour-power, it is the working class - the true referent of the term labour-power - and the movements internal to that class that are foundational.

There are several ways these claims have been interpreted. The most prominent is probably that of Antonio (Toni) Negri. Negri emphasizes the active, creative, innovative moment of 
the working class, to be contrasted with the reactiveness of capital. The working class is always the active moment of the relation; capital is always parasitic. My own sense is that this is where the critical difference between Negri and Tronti lies (although there are undeniable bases for such a reading in certain passages by Tronti). What mattered to Tronti was what Alberto Asor Rosa calls the discovery of a new concept of the working class, not as sociological category but as partisan viewpoint, what Franco Milanesi calls "political will" or Wille zur Macht. This Lukácsian reconceptualization of the working class - inflected by Nietzschean, Weberian, and Leninist insights - asserts a partisan knowledge embedded in the concept (little discussed but operative in Tronti) of "class composition" (for which one must turn to the invaluable work of Romano Alquati, some of whose texts have begun to be published by the impressive Viewpoint collective). Workers and Capital, then, is a book that sets out to reconceive Marxism through a reappraisal of the working class as the political foundation for a theoretical and political engagement with capital: the working class is organized, or it is not a class; the foundation of that organization is its partisan standpoint in inescapable conflict with capital; and hence the working class is immediately political.

There are several issues with this Verso edition, most glaring perhaps the complete lack of any scholarly (or merely informative) apparatus. This is particularly problematic for the editorials collected in the section "First Hypotheses". ${ }^{\mathrm{I}}$ Each of these editorials was written in the heat of the rapid changes in the industrial and political line of the Italian Communist Party, as well as in its internal debates, the formation of the first "centre-left" government (bringing together a Christian Democratic majority with various socialist groupings and the republicans), the changing role of the official trade unions, and the role of the Italian business confederation, etc. The editorials are largely incomprehensible, apparently contradictory, or seemingly doctrinaire without some understanding of that context. They are also reflective of sharp conflicts among the operaisti themselves, and among the various communist factions. Critiques of reformism, of the "partito unico", etc., can seem somewhat ritualistic, like the references to "the party", to tactics, and strategy. The risk - unavoidable I would contend - is that what are originally conjunctural analyses assume here the guise of a battle between universal philosophical categories. (This is something any attentive reader of Lenin should recognize.) But Tronti's thought - especially between 1958 and the I 980 - is developed, like Lenin's, in a way that is highly mediated by very concrete, material shifts in institutional and political alignments (from above and below), as well as by breakneck economic change and multiple crises of accumulation, legitimacy, and representation - with the consequent impact on everything from the forms of worker representation, internal migration, change in educational policy, and changing cultural forms and attitudes.

The edition appears rushed, with the translator making no interventions in the text, even to explain fundamental issues of language and terminology. Workers and Capital, Operai e capitale. Two categories, only one of which translates directly. The critical one, operai, is not simply "workers" but industrial workers. An operaio is almost always reducible to someone working on an assembly line. "Worker" is far too generic and can quite easily slip into the

I. These "hypotheses" were actually editorials first in Quaderni rossi (the founding journal of operaismo) and then, following a break instigated by Tronti, Classe operaia - hence the "new course" in the title of "Lenin in England". The book is divided into five broad sections: "Introduction: A Course of Action" (1966), "First Hypotheses" (1962-1964), "Initial Theses" (1966), "Postscript of Problems" (I97I), and the retrospective essay "Our Operaismo" (2006). 
ninety-nine per cent (at its extreme), or, as Michael Hardt and Negri write, anyone who works under the rule of capital. For Tronti, the standpoint of the industrial worker is very specific. Lose the specificity, you lose the central category of the book.

A few more words on the translation itself. In the Italian, this text combines an extraordinary theoretical density with an almost poetic concentration of expression, alongside a staccato style of surgical violence - for which Tronti is renowned and the Italian language is not. Arguably, only Tronti's contemporary, the poet, cultural critic, and translator Franco Fortini, was able to do analogous violence to the somewhat florid forms for which Italian is known, to morph it into a militantly theoretical and theoretically militant language. The task of the translator in rendering such a style is not a simple one, and not made easier by the extraordinary range of references, unacknowledged but unmissable for those with a grasp of this peculiarly heretical Marxist tradition, to thinkers and artists as different as Goethe and Brecht, Musil and Benjamin, Hegel and Mahler, Weber and Lenin, Nietzsche and Marx - to name only some of those most central to Tronti's thought. These are present in numerous allusions as well as in the fabric of the language. To take one example, the introduction "Linea di condotta", translated here as "A Course of Action”, is the Italian translation of Brecht's Die Maßnabme, which in English has appeared either as "The Decision" or, perhaps closer to the Italian, as "The Measures Taken". This reference to a specific play by Brecht is no mere affectation, but illuminates Tronti's own political stance. Many such references are missed in the translation. Moreover, for some reason, throughout the book, the translator removes the italics introduced into quotations by Tronti, rendering them as in the original source, as if these were a mistake rather than a chosen effect.

There are also baffling formatting issues; for instance, entire chapters presented without a single paragraph break, making the density at times excruciating, and the chance of orientating oneself impossible. At other times, paragraph breaks are introduced, something that might be necessary for our contemporary sensibilities, but not when they muddle the logic of argumentation - on pp. xxi-xxii of the introduction, for instance, where a single argument is split across two paragraphs, serving to obscure the powerful unity of intent. At others, there is no distinction between a new paragraph and where there is a double space between paragraphs, marking a stronger break in the course of the passage.

Crucially, there are numerous errors that subvert the meaning. To mention a few: on p. xviii, in a discussion of bourgeois social science, the translator has Tronti championing "human civilisation" against accusations that the workers' partisan viewpoint risks "pitching mankind back into barbarism". In fact, Tronti asks, "who said that human civilization" (which, in line with Asor Rosa's The Writer and the People is little more than a cover for bourgeois ideology) "is our dearest concern" (my emphasis). The meaning is entirely reversed. On p. I I 9 , the phrase should read: "It would be necessary to find some invariable commodity" - not, as in the translation, "some invariable community". On the same page, "Thus a quantity of wealth, utility or use-value is easily exchanged for what is, instead, a quantity of value" - not "easily exchanged" but "easily confused" (the term scambiato is the same for exchange/confuse, but the meaning is clear for anyone who follows the argument). And, amazingly, on p. 59, operaismo is translated as "a cult of the workers"!

It is a shame that we have had to wait so many decades for the first appearance of this book, from an excellent publisher such as Verso, only to be presented with a text beset by errors and limitations. For there are many ideas that have become central to much "radical left" thinking that can be traced to this book - most notably that of the "social factory", which finds its origin here and was embedded in the workers' enquiry (or co-research) involving reading Marx's Capital with workers, comparing it with their experiences, and innovating 
Marxian categories in the process, or helping orientate struggle through a comprehension of the critique of the political economy of the factory. At other times, Tronti shows precisely the differing contributions of Hegel, Ricardo, and Marx to the foundation of the critique in the category of labour-power as working class, in the long central "essay" in the book.

This is an immensely rich and provocative book - critical to any understanding of Marxist theory in Italy and beyond, and by no means devoid of insights for the present. While its appearance in English - over thirty years after the French and German translations, and two decades after the Spanish - is welcome, a full reckoning with its contribution will need to wait the appearance of an accurate critical edition.

\section{Matteo Mandarini}

Queen Mary University of London Francis Bancroft Building, Mile End Road, London E I 4 NS, United Kingdom E-mail: m.mandarini@qmul.ac.uk doi:I0.1017/S002085902000068 I 